\title{
Adapting Business of Energy Corporations to Macro-Policies Aiming at a Sustainable Economy. The Case for New Powering of Automobiles
}

\author{
Jose M. “Chema” Martinez-Val Piera, Alfonso Maldonado-Zamora, Ramon Rodríguez Pons-Esparver \\ ETSI Minas, Universidad Politécnica de Madrid, Madrid, Spain \\ Email: chemaval@gmail.com
}

Received October 25, 2012; revised November 28, 2012; accepted December 13, 2012

\begin{abstract}
A portfolio of new energy technologies has emerged in the first decade of the 21 st Century, and many of them could be used for restructuring the energy sector towards Sustainable Development. A key subject in this quest is the future of automobile, with possibilities on powering ranging from biofuels to Hydrogen Cars (HC), to Electric Vehicles (EV). In turn, the latter is closely connected with the need to deploy Renewable Energies (RE) for electricity generation. Within such new situation, countries and governments are aware that there are new tools for fighting Global Warming $(\mathrm{GW})$, and new policies could be established for winning this battle against $\mathrm{CO}_{2}$. All these initiatives will affect the future of energy corporations, notably hydrocarbon companies; and it should be noted that it will be difficult for the companies to define long-term strategies if energy policies convey upheavals, sudden changes in promoting alternatives and interruptions on activities. Hence, it is very important to adopt energy policies allowing a smooth evolution of the companies' activities to the new energy model. After analyzing the alternatives with a forecasting-backcasting methodology, an "eclectic approach" is proposed, with the Plug-in Hybrid car with Flexible Fuel (PiHFF) as the central paradigm in the coming promoting policies.
\end{abstract}

Keywords: Sustainable Energy Policies; Electric Vehicles; Corporation Adaptation

\section{Sustainable Development as a Worldwide Quest}

These initial years of the third millennium (A.D.) are evolving under a sort of paradox: the economic and financial perspective is rather obscure and without horizons, while the technology perspective is very positive and full of potential. The latter includes Bio-technologies, Communication and Information Technologies, Material Science and Nano-technologies, Space-related spin-offs and, of course, Energy technologies [1,2]. The list is not exhaustive, but Energy is a main block in it.

The technology perspective is so appealing that many people (scientists, journalists, politicians) speak about the upcoming Third Industrial Revolution [3], which would be based on Energy and Machines, as the previous ones. The First Industrial Revolution was enabled by Coal and Steam Engines, applied to industrial machines, navigation and trains. The Second one exploded from Internal Combustion Engines (ICE; see list of acronyms at the end of the article), petroleum products and cars, on the one hand, and electricity on the other hand. The Third one could convey EV and new energy sources, notably $\mathrm{RE}$ and Nuclear Fusion. Although mastering all these elements is still a challenge, it will take time, efforts and budget, and not all players will advance at the same rate. It is worth highlighting the potential merging of the two legs of the 2nd Industrial Revolution into a single stem in the 3rd one, if electric cars actually succeed in the new Revolution. Some people can consider this fact is a mere coincidence, but it seems there is a technical destiny in this merging.

This optimism about technology cannot run freely. A new and tight scenario has been set up by a strong paradigm inherited from the end of the 20th Century, namely, Sustainable Development $[4,5]$. It includes the need to stop human intervention in Climate Change (CC) [6-11], also known as the fight against Global Warming [12-14]. Some people (including politicians and journalists) consider that this problem is less acute and important than the Global Economy Crisis currently running, but there is a difference between both problems, which is similar to the difference between Physics and Economy. Laws of Economy can be changed or can evolve by human action. This is not the case for the laws of Physics. They cannot be changed.

A third type of perspective must be considered in order 
to complete the premises of the study. It can be called the organizational perspective; i.e., the capability to organize our forces at a corporate level, country level, continent level and finally, Worldwide, for modeling the future in a really good way, if not the best way. An important example in this domain is the Intergovernmental Panel on Climate Change (IPPC) [15] although it is not an executive body, but a purely scientific one. Even so, scientific evidence of GW was essential in the Kyoto Protocol, and it has been confirmed since then, what urges the IPCC to ask for a substantial reduction of Greenhouse Gases (GHG) emissions.

In the organizational perspective, a salient entity is the European Union (EU), which has likely been and continues to be the most committed body in the fight against $\mathrm{GW}$, and in the promotion of sustainable development (Directives 2003/87/CE on $\mathrm{CO}_{2}$ emission; and 2001/80/ $\mathrm{CE}$ on Large Combustion Plants). As most of the political decisions, those of the EU concerning these principles can be considered very rhetoric, but the commitment has been established in terms of numeric objectives, particularly in the EU Directive "20/20/20" 2009/28 CE establishing binding goals for year 2020 in reduction of GHG emissions, use of RE, and improvements in efficiency and energy savings, all of them in $20 \%$ variations. Of course, this is easier saying than doing, and some people consider this policy is just wishful thinking. It is important to underline that the actual rate of change in the productive sectors seems to be too slow, particularly in Energy. Many of the new technologies are not competetive yet, and some of them (notably, Nuclear Fusion) seem they will need about half a century for getting a place in the applicable portfolio. In other cases, as RE, the deployment is only possible thanks to strong subsidies and feed-in tariffs (as Spain's decree RD 661/2007), which is a distorting factor for current markets.

This paper addresses the difficult adjustment between micro-economics of the corporations and the macro objectives of energy and economy policies, particularly in relation to hydrocarbon corporations. Many papers [16] are devoted to state-level analysis, but they do not contemplate the very practical and fundamental problem of how to implement selected policies by the action of the corporations working in this field. Moreover, in a shortterm future, energy corporations of some countries will have to internalize the cost of GHG emissions, and a parallel market of emission rights will be established. This is the case of the EU, as regulated by Directive 2003/87, which includes a transient phase ending in January 1st 2013. That Directive has been transposed to domestic legislation in the Member Countries, as Spain's Law $1 / 2005$ and the RD 1370/2006. Although not all emission sources are contemplated in the same way, and external "clean mechanisms" are included in that market as flexi- ble actions, the actual fact is that $\mathrm{CO}_{2}$ will have to be incorporated as another cost in the corporations of the energy industries. Additionally, a better scientific insight is needed for clarifying the impact of natural catastrophes (volcanoes mainly) in the evolution of CC.

It is difficult to anticipate how strong and long lasting the enforcement of that legislation will be, because many specialists point out that GHG are a worldwide problem that cannot be addressed by individual decisions, even if they are taken by the EU. A key point is that coal has undergone the highest increase in consumption in the current Century [17] and one of the causes is that electricity development in China in the last decade has relied mainly on coal.

The next section presents a very brief summary of relevant facts of the Energy sector at large. Section 3 will be devoted to analyze some features and principles of corporations as living bodies that must survive in a competitive environment where the rules can be changed by laws, and laws can be changed by goals. The problem addressed is specifically focused on Energy, where two branches notably separated until this Century, the oil and electricity industries, can somehow merge in a complex new sector. The paper is then focused, in Section 4, on the global challenge created by the rising contents of equivalent $\mathrm{CO}_{2}$ in the atmosphere. This section also includes some considerations about the role of technology evolution as a global answer to that challenge. Section 5 presents a finer analysis of the technology evolution that seems more likely to succeed. Finally, Section 6 is devoted to how a corporation can deal with the problem of reshaping itself in accordance to the anticipated future. If some decisions are taken too early, they can take the wrong path. If they are taken too late, they can be useless for getting (or keeping) market share. We conclude with some recommendations on addressing the global problem, proposing a stronger link between transportation and energy sectors.

It is particularly important to speed-up technology development and to identify in due time legal and regulatory changes to define the new rules of the game, which must include the internalization of environment costs, notably $\mathrm{CO}_{2}$ emissions. However, such changes must follow a smooth track, so as not to induce a crisis is the hydrocarbon industry, which is a backbone of social and economical activities in most of the world. The smooth track proposed in this article can be called the eclectic approach.

\section{The World of Energy}

There is a broad consensus nowadays about the principles of Energy Policy:

- Security of supply (and the related objective of energy independence, in contrast to the existence of global 
markets).

- Reasonable (if not minimum) costs (which conveys economic competitiveness).

- Environmental quality (at local, regional and global levels; the latter being in close connection with the problem of GHG Effect).

In spite of this consensus, it can be seen $[17,18]$ that the actual situation of energy in the different countries presents a wide variety of cases, both in quantity (consumption per person) and quality (types of energy used). Few common points can be marked, notably the dependence of transport on oil products.

It is worth pointing out that the role technology could play in coping with the energy problems, as was pointed out in the EU "Green paper: Towards a European strategy for the security of energy supply" [19] where a complete analysis was attempted in order to meet the objective of the title without forgetting the restrictions in $\mathrm{CO}_{2}$ emissions. At the end of its Executive Summary was written:

"Every form of technological progress will help to reinforce the impact of this outline energy strategy". However, the technological analysis was rather conventional, with two controversial poles (coal and nuclear) and a clear quest for RE and Natural Gas (NG), but RE were not foreseen in the way they have evolved. On the side of the demand, emphasis was put in energy savings in Housing and Transportation, without including any reference to $\mathrm{HC}$ or EV. In 2000, those inventions were con sidered out of the mainstream in terrestrial mobility.

It must be noted that in many countries, notably Spain, the strategy outlined in the Green Paper was clearly followed. In 2000, electricity generation by NG and RE was very limited, and it underwent an impressive development in one decade, reaching very high values at the end of 2010 [20] after an interesting deployment [21-28] including unanticipated effects [29]. In 2010, 23\% was generated by Gas-fired combined cycles (GCC), and $22 \%$ by RE (wind power being the biggest contributor with 16\%).

In the Technical Annex of the "Green Paper" it was again underlined the importance of technology, with the following strong statement: "Energy technology will be critical in meeting the needs of current and future generations" but at the same time there was a caveat about the price to pay for such development: "In the energy field, technological change does not come cheap", and some advice was given to promote the development of RE by state funding or feed-in tariffs.

In the last ten years, the technology scenario has changed. Looking ahead to the next decade, it is seen that the portfolio of emerging technologies has widened quite a lot, and some of them are being proposed as new tools for satisfying human demands in very traditional sectors, as on-ground mobility, where $\mathrm{HC}$ [30-34] and EV [35-40] have appeared as contenders versus conventional ICE. Additionally, new electric grid devices have opened the way for the so called Smart Grids [41], which will use internet and telecommunication technologies, so helping to optimize the total electric system in a country or a macro-region $[42,43]$.

Most of these technologies were not in the picture at the turn of the century. A new driving force was needed to refresh the interest for new energy technologies, and this force was the Kyoto Protocol. Many scientists and some governments (notably, the Bush's Administration in the USA) considered that restrictions per se (the Kyoto recipe) as a blunt answer to the problem, and pointed out that there were technologies to be analyzed or revisited to find a better solution to the GW problem. To some extent, the IPHE (30), and Nuclear Generation 4 (and the Generation 4 Forum [44]) were also a product of this situation after Kyoto. Above all, any low-carbon energy source or energy technology was considered a priority for restructuring the Energy sector, mainly RE [45] and Carbon $\left(\mathrm{CO}_{2}\right.$, properly speaking) Capture and Sequestration (CCS). Its most visible initiative is the Carbon Sequestration Leadership Forum [46].

Although most of these technologies are evolving very slowly, which is a main part of the problem that must be solved, it has become clear that a big change in the Energy sector is possible. However, the stiffness of the industry and the markets, and the lack of maturity and economic viability of the new technologies are keeping the status quo. In fact, the most relevant reaction to energy needs in the USA nowadays is unconventional gas (mainly shale gas). It is true that it is not conventional in a strict sense, but it is NG and can be used as such.

$\mathrm{NG}$ is going to be at the very center of the ongoing evolution in the Energy sector $[47,48]$, and this fact includes both short-term initiatives (as the shale gas [49, 50], already running) and long term ones, as methane clathrates [51-55].

\section{Interplay between Electricity and Hydrocarbons}

Although a few countries have started earlier, the global move towards GCC exploded by the end of the last century. Reasons for such extended deployment can be found in some facts that must be kept in mind, because they are rather unique:

- NG global availability (although not cheap, indeed; but cheaper than oil in energy terms).

- Small specific cost investment (the lowest within power plants fully manageable and reliable).

- Short construction times (taking advantage of prefabrication of the main components, particularly the gas turbine). 
- Operation flexibility (within some margins depending on the project). It is worth citing that in Spain, where a GCC capacity of 24,000 MW has been built in less than 12 years, these units act as back-up power for Wind parks and Photovoltaics.

The combined factor of time and money has been decisive for such fast deployment of these power plants, and it is not easy for any other thermal generation technology (nuclear, coal, oil) to compete with gas in an open market. Table 1 presents a concept that can help explain the current evolution of generation capacity in liberalized markets. It is the "investment burden", expressed as the specific investment times the construction length. The smaller the "burden", the simpler the decision to invest. This concept has been coined in this work, and gathers a lot of qualitative information on the subject of time value of money.

A different situation is found in centrally planned economies, where coal or nuclear can receive a special deal as long-term programs, in order to guarantee better price stability in the long term. This is the case of China, particularly for coal $[17,18]$. In fact, coal has undergone the fastest growing rate of all energy products in these years of the new millennium, and China was the explanation. However, such long-term construction programs are not suitable for a free market, where gas power plants will very likely preserve its position of dominance [48].

\section{Challenges for Energy Corporations}

Commercial corporations are driven by profit. This does not mean short-term profit only, although any corporation will try and avoid short-term losses so as not to start a phase with so many negative features that could seem of going broke. In fact, a second fundamental objective of corporations is long-term viability, which is the guarantee to make profits to satisfy the corporate plan. Many corporations have specialized departments in Business Development and others rely on external consultants, but the final decisions on the future are obviously taken in

Table 1. "Investment burden" evaluating the adaptability of different power plants to a free market on the basis of construction time and specific investment cost.

\begin{tabular}{cccc}
\hline Plant type & $\begin{array}{c}\text { Const. time } \\
(\mathrm{yr})\end{array}$ & $\begin{array}{c}\text { Spec. invest. } \\
(\$ / \mathrm{W})\end{array}$ & $\begin{array}{c}\text { Investm. } \\
\text { burden }\end{array}$ \\
\hline GCC & 1.5 & 0.75 & 1.13 \\
Wind power & 1.0 & 1.2 & 1.2 \\
Photovoltaic & 0.5 & 4.0 & 2.0 \\
Coal & 3.0 & 1.5 & 4.5 \\
Solar thermal & 2.5 & 5.0 & 12.5 \\
Nuclear & 8.0 & 4.0 & 32.0 \\
\hline
\end{tabular}

the very core of the corporation, including considerations on environmental factors, such as industrial ecology [5669].

Those strategic lines must take into account the potential evolution of all aspects of life and technology that can have an influence on the market or sector where the corporation works. They can be considered as the boundary conditions of the problem, and they can be different in nature: social, financial, legal, technical and so on. And this is the point where a substantial difference is found between corporations in general and corporations working in the energy industry, mainly in the domain of primary energy and electricity generation: the difference is the strong influence of energy policy objectives in the definition of the sector, including the case of liberalized markets.

No other economic field is so dependent on current international or global decisions as energy industry, which is (or will be) totally affected by decisions as the Kyoto Protocol, or the EU directive 2009/28 usually known as 20/20/20, already cited. A new situation appears now, with liberalized but regulated sectors, which must comply with global objectives. One by one, corporations are not obliged by those decisions, but governments must do something to meet the objectives, and the first reaction (very simplistic, in some cases) is the so-called "indicative planning", where some types of investments receive subsidies and/or feed-in-tariffs, to stimulate some actions reducing $\mathrm{CO}_{2}$ emissions and/or increasing RE consumption.

Such a new framework will represent a quantitative change, but this is only part of the problem. It can be anticipated that a qualitative change, associated with emerging technologies, will still have a major impact in the energy corporations. The technology change will not only affect the Electric Sector, as has happened in the previous decade with GCC and Renewable Energy Sources (RES), but the entire energy system, because it will affect automobile transportation, connecting it with the rest of the energy system, particularly electricity generation and distribution. It could be such a deep change, that corporations would have to transform themselves to adapt to a new situation, coming from different technology cultures, and moving to a new one. Technology evolution alone would likely not be so powerful as to motivate a qualitative transformation of the system, but it will be pushed ahead by Sustainable Development decisions.

The impact of this transformation on a given energy corporation cannot be addressed as an academic exercise or a research subject, and it falls into the domain of consultant strategies and the like, which must be run in a very confidential way.

The general impact on the corporations of the energy 
sector is indeed a general concern that can and must be studied as an academic subject to try and find recommendations for obtaining the best outcome from the changes ahead. The empathy between the macro level of international and decisions and the micro level of corporation daily life is a fundamental point. Paving the way in a well-understood framework is much less risky than reacting against unexpected facts.

\section{The Future of Energy: Forecasting-Backcasting}

$\mathrm{CC}$ is considered as the first global challenge in human history, needing a global answer based on soundly established science, which points out the need of limiting the atmospheric contents of GHG [15]. A first reaction (the Kyoto spirit) was to establish emissions restrictions, but in a few years a deeper change has appeared, based on technology. The global challenge was clearly described by the IPCC. Although some critics have disagreed with these very long-term weather predictions, there is a rather general consensus on the need not to trespass a threshold of $\mathrm{CO}_{2}$-equivalent contents in the atmosphere, be it 450 ppm, 500 ppm, or a similar figure. Enforcing this limitation by consumption restriction was something difficult to accept, in spite of said Kyoto spirit. Nevertheless, the situation is becoming totally different because of technology evolution, with two main factors, which can give a global answer to that global challenge:

- Low Carbon technologies, with three main routes (for the moment?):

- Renewable Energy Sources, notably for electricity generationp;

- $\mathrm{CO}_{2}$ capture and sequestration;

- Nuclear technologies (Fission and Fusion, which present very different problems, different energy potential and very different time span to maturity).

- Technology evolution in automobiles, mainly on Green cars, which include a set of possibilities as:

- Biofuels [70];

- Gas to liquid processes;

- Hydrogen cars;

- Electric vehicles.

Most of the topics are quite connected with the hydrocarbon industry. RES need a back-up, which is mainly provided by gas power plants. CCS could play a role in shaping the future around $\mathrm{CO}_{2}$, which will directly or indirectly affect also hydrocarbon consumption. For instance, a sizeable sequestration of $\mathrm{CO}_{2}$ produced in coalfired power plants would alleviate the pressure on $\mathrm{CO}_{2}$ produced in transportation.

Cars are currently powered by petroleum products, and this is the field where a deeper change could take place. As fuel cells and new batteries emerge as industrial components, it seems that conventional fuels will have to compete with $\mathrm{kWh}$ or with $\mathrm{H}_{2}$ production process.

Is it by chance that this technology evolution has gained momentum when it seemed it was needed? Of course, not. Some of the technologies were known for years, but they could not find any niche to compete. Technology evolution has been boosted by concerns on $\mathrm{CC}$, and a sort of feedback loop has been closed.

\section{Methodology to Study the Challenge. Forecasting}

Forecasting can give us a picture (or a movie) of the future, starting from the current situation and projecting the inherent capabilities of each line towards the future. This technique has been widely used in many fields and with many purposes, particularly for anticipating the demand of energy, but it can not be considered just a statistical exercise. It is true that a good statistical model helps obtain better results, but the main requirement is to make a good estimate of the parameters featuring the statistical model. Adjustments to previous phases are a way to calculate these parameters, but in this case it does not seem applicable, because of the quantitative and qualitative changes in the behavior of the system.

Some lines of research present a threshold, or a breakthrough, and results are almost negligible if the threshold is not exceeded. This is what happens with Nuclear Fusion, which needs to reach ignition to become an actual promise. This threshold seems higher than anticipated, and the outcome is that Fusion seems to be always 40 years ahead. Forecasting in this case is extremely difficult, and Fusion does not fit in the picture for the moment. The rest of Low Carbon technologies and New Transportation technologies can fit into the forecasting without major difficulties, with the exception of social opposition to some of them, usually for environmental and safety reasons. This point mainly applies to Nuclear Fission and CCS, but it can also affect some RES as off-shore windmills and above all, Biofuels (or Biomass in general). A clear example of failed forecasting was Spain's Plan of RES Fostering (1999-2008), which put a lot of emphasis on electricity generation with biomass, and there was a severe failure in that field.

Backcasting has complemented Forecasting in recent years $[63,64,71-73]$, to improve the tools for shaping the future in order to achieve a sought situation. This method has been activated to some extent by the $\mathrm{CO}_{2}$ problem, because the goal was foreseen, i.e., the level of $\mathrm{CO}_{2}$ concentration in the atmosphere that would be acceptable, which could be taken as a goal. Backcasting could identify potential roads to reach that goal, for instance, by sharing the total emissions among countries, or among technologies, or both.

Forecasting is nonetheless more familiar to everyone, 
and seems simpler to apply, although many predictions have gone totally wrong. Even so, it seems mandatory to carry out an exercise of forecasting (or prognosis) in any paper probing the future. The summary of that exercise is presented in Table 2 . The four technologies previously considered in the field of automobile powering are assessed versus some fundamental criteria, chosen according to an extensive literature review [70,74-82], plus some expert judgment from the authors. The last column presents the average value of the appraisal of said technology against those criteria. The value is expressed in a black-grey-white scale. Darker color in a cell means poorer appraisal.

Criteria applied to Table 2 correspond to the following concepts, considered for mid and long terms (up to midcentury):

1) Primary sources;

2) Conversion technologies;

3) Suitability to be stored in a car;

4) Technical marketability (including investments, both specific and global ones);

5) Public acceptance;

6) Actual external limitations (as materials for batteries);

7) Positive effect in $\mathrm{CO}_{2}$ emission reduction.

Last column is a qualitative average.

The judgment underlying Table 2 and the way to present it, only corresponds to the authors, but it has been elaborated after considering very many pieces of technical information. Appraisals of Table 2 are arguable, but they indicate in a qualitative manner the inherent value of each technology.

This value should be the basis to mobilize a change in the automobile sector towards Sustainable Development, and identify the places that could convey stronger difficulties. In the table, an average evaluation has been given in last column, but there are alternative methodologies to define the final appraisal. For instance, multiplication instead of addition puts more emphasis on the weakness of a criterion evaluation, and gives clearer classification. Similar result can be obtained using, as global evaluation, the worst appraisal in any criteria, for a given technology. This is the principle of the weakness of a chain, which

Table 2. Forecasting appraisal of technologies with potential of change in the automobile sector.

\begin{tabular}{lllllllll}
\hline Tech \& Criteria & $\mathbf{1}$ & $\mathbf{2}$ & $\mathbf{3}$ & $\mathbf{4}$ & $\mathbf{5}$ & $\mathbf{6}$ & $\mathbf{7}$ & avg \\
\hline Biofuels & 3 & 3 & 1 & 1 & 2 & 4 & 2 & $\mathbf{2}$ \\
Gas to Liquid & 2 & 5 & 1 & 1 & 2 & 3 & 4 & $\mathbf{3}$ \\
Hydrogen Car & 2 & 3 & 5 & 4 & 4 & 3 & 2 & $\mathbf{4}$ \\
Electric Vehicles & 1 & 2 & 3 & 3 & 1 & 4 & 1 & $\mathbf{1}$ \\
\hline
\end{tabular}

corresponds to the weakest link. If the difficulties associated to a criterion are not overcome, the full deployment cannot take place. In any case, for both ways of considering the appraisal, the global result of the exercise is the same, and the priority order given below:

1) Electric Vehicles;

2) Biofuels;

3) Gas to Liquid;

4) Hydrogen Cars;

This appraisal is an integrated view, but forecasting also needs to take into account the time-dependent evolution, and the interferences that can appear among different elements of the scenario, including interferences among technologies themselves. It is obvious that all technologies will not be developed at the same speed, and only one or two will be deployed up to commercial level, and this must also be part of this analysis.

Not all forecasting studies on the different technologies identify the EV as the most promising technology to reduce oil dependence and to reshape the transportation sector to a cleaner activity. Some studies done or supported by the USA Department of Energy [83] do not give too much credit to the deployment of EV and assume that Biofuels will be the natural substitute for petroleum products.

Biofuels $[65,70]$ will mainly stem from sugar crane for making ethanol in a first stage, followed by corn for the same objective, and soy for making diesel, with a long term quest for cellulosic biofuels. One of the reasons for adopting that choice is that it requires the minimum transformation of the infrastructure of the whole system (related to Light Duty Vehicles, which will represent an inventory of 300 million cars in the USA by 2035). Indeed, gasoline engines have already some flexibility to accept small percentages of bio-ethanol, and full flexfuel engines will run on E85 (85\% of ethanol).

It is obvious that the "2011 Annual Energy Outlook" [83] does not make a bid for technology transformation, and relies completely on hydrocarbons and similar chemicals. It was already so in the previous reports, where the central issues were dominated by NG either from Alaska or from shales. The last report puts more emphasis on Biofuels, in spite of the problems they are already causing in Brazil and elsewhere [84-87].

The overall picture of energy values related to this problem seems to indicate that a "Biofuel industry" can be developed worldwide without too much distortion of the current agriculture activities; but a deeper analysis points to deeper problems. It is estimated that the total solar energy captured by living beings of all kind amounts to $3000 \mathrm{EJ} /$ year. It is about $0.08 \%$ of the total solar radiation impinging on Earth. It is six times as large as the human demand of primary energy, which is close to 10 billion tons of oil equivalent per year, which is about 420 
EJ/year (without accounting for primary biomass consumed as an energy good, which is about $40 \mathrm{EJ} /$ year additional). Oil products amount to a little less than 150 $\mathrm{EJ} /$ year, which is about $5 \%$ of the energy capture of biomass. So, the disturbance seems acceptable, but the full picture contains other elements which must be accounted for.

The energy contents of the biomass for our food are one twentieth $(1 / 20)$ of the energy we consume for other uses, i.e., $23 \mathrm{EJ} /$ year. If harvesting and commercialization efficiencies are taken into account, the raw materials of our food chain amount to $50 \mathrm{EJ} /$ year approximately. This value must be taken as the real reference for any manmade intrusion in the biomass world with the goal of producing new types of commercial products (some genetically modified cellulosic plants, for instance) or already known products (sugar cane, soy beans, palm oil) at a scale much larger than the total current effort for our food. In fact, if one third of the oil products should be replaced by biomass products, it would be necessary to double, at least, the total activity devoted today to agriculture. Of course, this is not an impossible quest, but some warnings should be expressed on the potential distortion caused in agriculture, and the potential impact caused in the environment (particularly, in some privileged ecosystems of high biological vitality).

Precautions on biofuels are mainly rooted in the natural roots. From the complementary technology point of view, some important efforts have been made, and high quality processes and products (www.nesteoil.com) are already available but not at a global scale. Technology evolution in this field has been boosted by suitable policies implemented in several well-developed countries. The EU directive on RE, for example, requires that they should account for at least $10 \%$ of the energy used in traffic and transport by 2020, National legislation in Finland has targeted $20 \%$ content by 2020 , and legislation in the US will require $20 \%$ content by 2022 . All these figures originally meant biofuels, although other alternatives such as electric cars charged with electricity from RES could also be accepted now to meet that goal.

Nevertheless, it should be kept in mind that total ethanol production is about 700 thousand barrels a day $(673.5$ thousand/day in 2004 [70]) and biodiesel production is close to 50 thousand (39.6 thousand in 2004, but it is increasing). These figures are much lower than the final consumption of gasoline, which is about 20 million barrels a day, and diesel, which is slightly higher, 21 million barrels/day. Although it is claimed by biomass proponents that they would require the smallest modification in automotive infrastructure as compared with other alternatives, Biomass could produce a huge perturbation in the downstream oil industry, although the main upheaval will likely happen in agriculture, forestry and the cycles of natural nutrients.

\section{Bridging the Gap between Now and the Sustainable Future. The Role of Technology}

It has been pointed out by many authors that we have in the history of humanity, a first global challenge, which is the fight against GW. Indeed, other challenges affecting billions of people are very important, as the fight against Hunger and Poverty (Objectives of Millennium, United Nations) but they are localized in space, and should be considered specific challenges, strongly related to the political arena. It has also been said that several lines of research have been proposed for developing new systems and processes that could contribute to meet the goals of that challenge.

A backcasting exercise can shed some additional light on this problem, including in this case the electricity part of the picture, which will become much more intermixed with hydrocarbons than ever before.

Figure 1 shows the final goal in the left-hand-side of the picture. The goal is the origin of the plot, which develops towards the right-hand-side, representing going back-wards in time, until the current day.

Three ways are identified as potential causes of GHG emission reduction, namely;

Technology evolution \& revolution;

Limiting quotas per country;

Changes in habits \& working conditions.

Last line, "changes in habits \& working conditions" is outside the scope of this paper. It sounds like science fiction, but some of those things are likely to happen. The second line is also out of our domain, although it was the pathway taken in the Kyoto Protocol. It has had many problems for confirmation by some important countries such as the USA and China. It is not a simple story, because an equal quota for all persons will not be fair, if weather conditions, geography, population densities and other factors are not taken into account. The Kyoto spirit of fighting the problem by establishing restrictions was a simple and prompt response, and not much more was possible in the time span available to prepare proposals. Much more time was needed to set up alternatives to that rough reaction, but in a few years the scenario changed a lot, and many technological proposals represented very sound options to really cope with the challenge.

To a large extent, technology had created the problem, and to a large extent, technology is ready to solve it (by the way, neither creating confrontation among countries, nor anxiety on people. Individuals just can change habits by their own will, not by force).

The technology domain points out that there are a set 


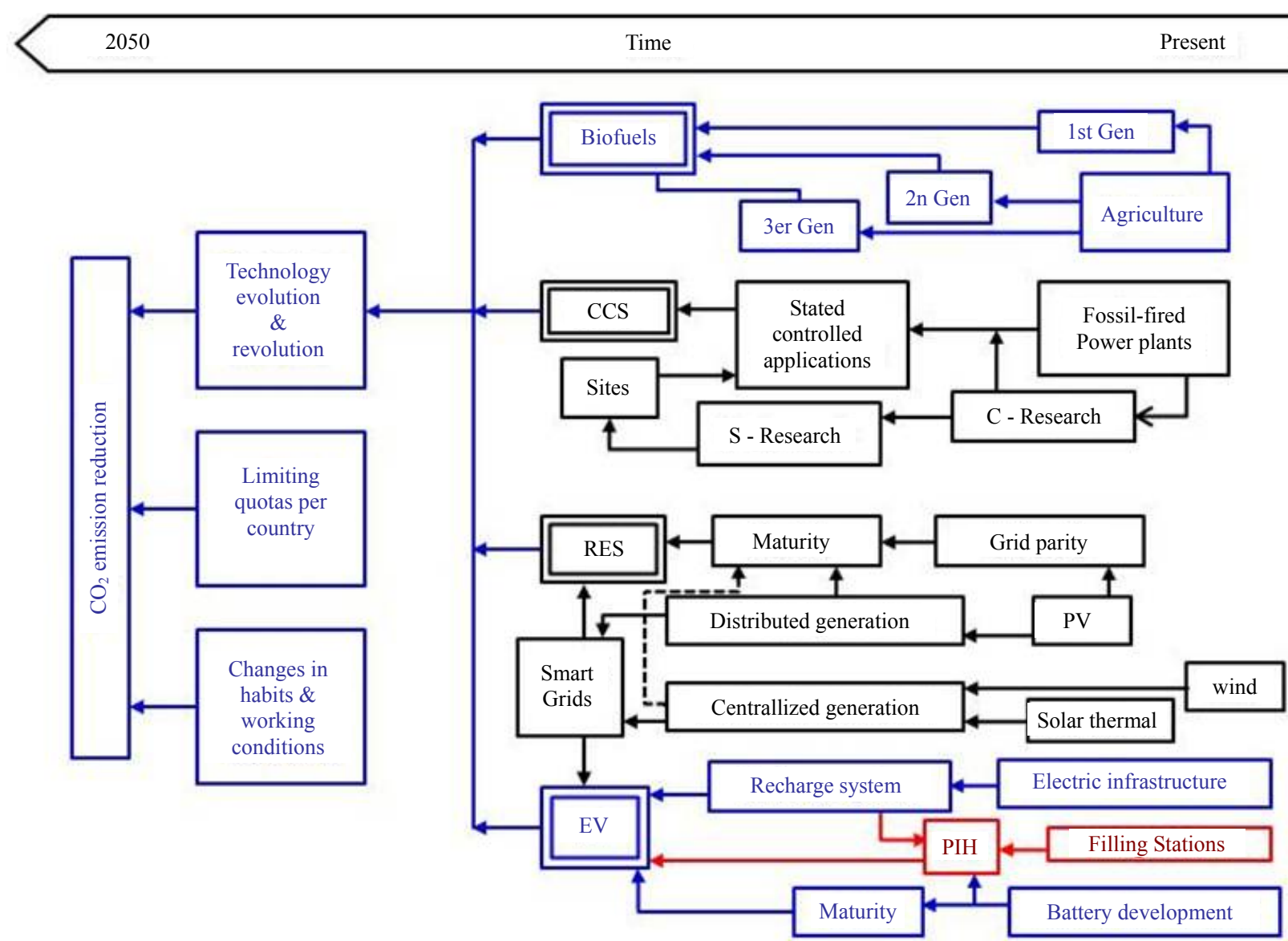

Figure 1. Backcasting exercise starting from the goal of reducing significantly $\mathrm{CO}_{2}$ emissions by 2050, going backwards in time until present.

of technologies which can produce a significant reducetion of $\mathrm{CO}_{2}$ emissions, but they have to overcome some problems (schematically indicated in the figure). A detailed exercise on that figure should include the expected reductions of emissions under different hypotheses of technology development and primary energy sources availability, but in our general analysis the figure is limited to qualitative descriptions.

It is worth commenting on the special case of CCS. Sites for deep underground $\mathrm{CO}_{2}$ storage are the critical point in this field. Early experiences in The Netherlands, Norway and Germany, where public opposition promptly sprung, are highly indicative. Some of the opponents seem to act under the "lake Nyox" syndrome [88,89], remembering an eruption of gigantic $\mathrm{CO}_{2}$ bubbles from the Nyox volcanic lake (Cameroon), in 1986, with 1746 casualties. A much smaller catastrophe had happened six years before in lake Manoun, also in Cameroon. Nowadays, those lakes are under surveillance for early detection and emergency declaration, but that risk was poorly known before those unexpected emissions. Of course, the small but existing volcanic activity of those lakes is in the very root of the emissions. The situation would be absolutely different in a depleted reservoir, replenished with $\mathrm{CO}_{2}$, or in a saline dome that has not suffered any geologic disturbance for several hundred million years. Enhanced Oil Recovery projects that considered CSS goals could be added in to this list.

In any case, the special features of CCS led us to advise its application in a totally transparent way, under regulation and control of public authorities, following the example of the Nuclear Regulatory Commission [90]. It is not clear at this moment to which extent CCS will be needed to meet the requirements of the fight against $\mathrm{GW}$, but it is a technique that can work with similar guarantees to any other modern technique. From this viewpoint, CCS must be developed and the sites must be characterized, for the sake of having a back-up solution to the rest of low-carbon technologies under consideration. Hence, it seems an authority-controlled or at least strongly regulated activity is required, much more than a field where private initiative could be carried out by corporations.

On the contrary, RES is a field fully open to private initiative, although public-funded programs of $R \& D$ seem absolutely necessary for advancing in the learning curve of each technology. A similar advancement is 
needed in EV, which can be considered complementary to RE.

The whole electric system will be deeply affected by the deployment of EV. The complete recharge system will still be denser than the current net of filling stations, including privately owned individual recharge posts. Electricity infrastructure will expand quite a lot, and electricity consumption will undergo a dramatic increase, whilst gasoline and diesel will undergo a significant decline for ICE vehicles. Of course, this tremendous upheaval, which is expected by many as a blessing, can evolve into a crisis with many negative consequences. This change, the 3rd Industrial Revolution for some prophets, has to be properly managed by government and international authorities so as not to transform a great opportunity into a disaster.

Energy corporations have to prepare themselves for an efficient adaptation to such a "revolution". Of course, technology evolution cannot be so fast as to hamper said adaptation, but lazy and badly prepared corporations will face stronger problems for survival than well equipped corporations. The equipment should include activities of technology surveillance and, above all, internal analysis to identify weaknesses, strengths, risks and opportunities. Those analyses should be done for any conceivable scenario, as the ones exposed in many publications (notably WEO [18]) of forecasting and backcasting. Governments and international bodies will establish policies according to the political and environmental pressure, (as the Directive "20/20/20" 2009/28/CE of the EU), and the reality is that technology is already here to face that challenge, although the specific technologies dominating the market in a given phase cannot be anticipated in advance. Nevertheless, some additional investigation can be launched into the future.

\section{A Choice of Strategic Lines}

Corporations will have to use the conventional tools for corporate planning in order to prepare for adaptation established in this field, including consideration of market inertia and producers' reactions against threats to the established industry.

The current car industry and the ground transportation structure fully relies on the conventional petroleum industry, and the very many appealing factors of this industry have been the main pillar for large scale social and economical development for more than one century, at least in the industrial and post-industrial economies. A change in this sector (petroleum + ground mobility) could entail deep perturbations in social and economic welfare, if the system does not evolve smoothly from the current situation to a carbon-free economy with a much lower direct dependence on oil (as we approach the oil-peak) and more efficient use of natural resources (particularly methane, including clathrates, permafrost and other unconventional gas).

As already stated in previous sections, biofuels is an important field of interest. Bio-ethanol and bio-diesel are already embodied in many commercial products for transportation. A controversy appeared from the so-called First Generation Biofuels, very closely connected with standard agriculture products. The dream was to develop a Bio-refinery, but the critical problem for this lies in its roots, i.e., the vegetable world $[70,85,87]$. The current level of hydrocarbon consumption is about 8 times as large as consumption of traditional biomass for modest energy application, notably in developing countries. It is very hard to identify how to evolve from standard agrilture and forestry to bio-refineries. In most of the cases (as Finland's wood industry) the added value of other applications (furniture, paper industry) is even higher than the energy value.

Global (well to wheel) analysis of different technology scenarios point out that EV [75-77] with a relevant role of plug-in hybrids as a long-lasting intermediate step, will offer the highest efficiency, and will minimize conmination in populated areas. The plug-in hybrid approach seems to have the better characteristic for a smooth, although fast evolution in automobile for reducing $\mathrm{CO}_{2}$. As an illustrative case for this quest, we can consider that a new vehicle of medium class will contribute an average emission of $125 \mathrm{~g} / \mathrm{km}$. An electric car would consume around $0.14 \mathrm{kWh} / \mathrm{km}$. This value will rise to 0.17 if the efficiency in charging the battery is accounted for. In Spain, an average value of $\mathrm{CO}_{2}$ emission in the electric generation system is slightly less than $400 \mathrm{~g} / \mathrm{kWh}$; which means less than $70 \mathrm{~g} / \mathrm{km}$. The situation will improve if coal-fired power plants decline in activity (they generate $1 \mathrm{~kg}$ of $\mathrm{CO}_{2}$ per $\mathrm{kWh}$ ) and RES continue to increase their generation. As a reference, GCC produce between 350 and 400 grams of $\mathrm{CO}_{2}$ per $\mathrm{kWh}$. With a gasoline engine, a car can have $\mathrm{CO}_{2}$ emissions between 110 and $140 \mathrm{~g} / \mathrm{km}$. Should gas be burnt in a Combined Cycle, an electric car fed with that electricity would have (indirect) $\mathrm{CO}_{2}$ emisons between 55 and $70 \mathrm{~g} / \mathrm{km}$.

The outcome of this change will be a cleaner environment in cities and much lower $\mathrm{CO}_{2}$ emissions in the planet, but the economic side cannot be ignored, because RES need for subsidies or feed-in tariffs (or both) and such a situation is not "sustainable" at all. On the contrary, despite some side effect generated by OPEC, hydrocarbons constitute a perfectly-running market, supporting a fiscal burden as no other product, at least in Europe.

The Hydrocarbon industry will face a change in this "energy and technology revolution", because there will be a decrease in direct consumption in vehicles, and an 
increase in electricity generation in high-efficiency plants, as combined "Brayton + Rankine" cycles and new freepinning gas turbines. Battery recharge will be as popular as gasoline filling, and both services could be done in the same place (for instance, current filling stations abiding by some safety rules [91-94], will include battery recharge and replacement $[42,95]$. This scenario would convey a profound transformation in many industries, and it will likely be dramatic in energy infrastructures, where a true interpenetration will likely appear connecting gasoline and diesel distribution to electricity, with "dual filling stations" providing liquid hydrocarbons and battery replacing. Customers will have to pay for the difference in charge between the replaced battery and the substitute, and for the difference in quality, because of performance deterioration with time (which will have to be evaluated by a rapid measurement of relevant variables in each battery).

Hydrocarbon corporations will have to follow an "adaptation mechanism" to evolve at the required speed. Of course, very long-distance and autonomous transportation units, as ships and airplanes, will remain oil-dependent, directly; but a sizeable fraction of the hydrocarbons will be consumed through electricity. Moreover, the formerly cited scenario of "dual filling stations" distributed for all the geography of an advanced country will have to be deployed before the actual deployment of EV.

Of course, hydrocarbon corporations will have to define their "adaptation mechanisms" which can be commercial (diversification of services) or technological (participation in the new energy conversion mechanisms). Merging with complementary corporations could also be a right tool. In any case, it seems advisable to start an exploratory phase in order to have a deeper insight into the future.

The uncertainty level is still very high about the impact and effects of those futuristic scenarios, but the warnings on $\mathrm{CC}$, the problems with petroleum availability at a reasonable price, and the appearance of new technologies seem to aim at the same target of evolving towards sustainability. In that quest, actions and reactions of hydrocarbon corporations will be critical; and they are still to be identified.

Business as usual is out of question in the oil industry, but a last point must be taken into account; there are also new roads to be explored for increasing oil reserves, particularly shale and sand oil. Heavy oil and ultra-deep off-shore oil have been in the portfolio of corporations for a long time, but they must be accounted for in long-term policies with the perspective of special strategic assets. Some industry experts such as Dr. Kazemi [96] estimate that about one trillion barrels of oil is waiting to be discovered, in addition to the similar amount that is "proven" reserves waiting to be produced. However, these sources would be more expensive than conventional ones, and would likely require a modified refinery processes. They must be considered, but they will likely remain as resources, for being exploited in a long distance future. This is also the case for gas-hydrates, that could have estimates of original gas-in-place exceeding 10,000 trillion $\mathrm{m}^{3}$ [97-100]; with estimated resources over one hundred trillion barrels of oil equivalent [100]. Note that current oil consumption is 85 million barrels of oil per day (mmbpd) and a peak could be reached in 12 or 15 years at $100 \mathrm{mmbpd}$. The IPCC and other forecasters point out the necessity to reduce that value to less than $50 \mathrm{mmbpd}$ by 2050 for limiting GW to acceptable levels.

We know now that technology can drive us to that goal, and a sort of competition has been outlined between Biofuels and EV. Pros and Cons of each option have been briefly commented (particularly in relation to DOE's "Energy Outlook" 2011), and have been treated in the bibliography [64-67,73]. It seems therefore that a choice has to be made between those options, and that situation is not desirable for any corporation, because the general framework will be decided by political opinions, presumable at a high international level, and this situation will not allow a corporation to adopt long lasting strategies, because of fears of policy changes.

At this foreseeable crossroads, the following "eclectic proposal" is introduced in this paper as a smother and more controlled entry into this period of competition and possible turmoil. The proposal can give time for better founded and cheaper technologies (for instance, for electricity generation from RES); can relax the anxiety of the "recharge syndrome" created by an autonomy range in the EV, which is much shorter than the standard autonomies in current cars. The "eclectic proposal" is to select the "plug-in hybrid with flexible fuel" as the dominant car in the coming decades. The term "flexible fuels" [101] means that they can run with a range of mixtures between oil products (either gasoline or diesel) and the corresponding biofuels (either alcohols or bio-diesels). Some relevant reviews on that topic are found in the literature [102-112]. In that way, the current effort on Biofuels [113-119] will not suffer a sudden halt, and the promising world of EV will have the possibility to mature without big expenses in the short term. Indeed, those technologies that are presented as confronting ones can be complementary.

\section{An Eclectic Summary}

At the end of the 20th Century, Sustainable Development [4] was proposed as a new paradigm to guide general policies, and within that context $\mathrm{CC}$ was recognized as a 
fundamental global problem, connected with the human emissions of $\mathrm{CO}_{2}$ [6-9]. First reactions were based solely on establishing emission quotas; but early in the $21 \mathrm{st}$ Century some important technology proposals were presented as new ways for creating a Sustainable Energy Sector. This was a profound change of philosophy, and will have a profound impact on policy making in Energy, which in turn will produce a deep change in the Energy industry. Nevertheless, non-anthropogenic $\mathrm{CO}_{2}$ emission, mainly those released from volcanoes, should be strongly considered as boundary conditions in the resolution of the CC problem. Theories on this subject [120-131] point out the importance of those natural catastrophes on weather variations. Those theories are supported by observations of modern eruptions [132-142] and by indirect evaluations of volcanic activity in the past [143-157].

Of course, such a big transformation will need a previous development of the required technologies, ranging from RES (including Biofuels) to EV, as well as huge investments, notably in the deployment of recharge infrastructure and, even more, in vehicle manufacturers and component makers. Even hydrocarbon consumption will also be partially oriented to electricity generation, because the global efficiency for car transportation will be better, if batteries finally achieve a level of maturity able to support such a substantial change [81-85]. In this scenario with so many questions marks, which will not reverse to past structures, the pathway of the PiHFF seems to be the most likely one, and the most convenient for all stakeholders in the energy industry.

A selection of keywords and corresponding challenges can be made from the previous sections, but the main conclusion is the technology capability to reshape the future of Energy, including an dramatic reduction of $\mathrm{CO}_{2}$ even if hydrocarbons continue to play a very prominent role, because the general efficiency will increase by a factor of two in transportation, if the EV deployment succeeds. This approach between electricity and hydrocarbons opens a lot of possibilities, and corporations from both industries should take advantage of them, overcoming the traditional communication problems between both sectors.

The macro-economy of the new situation will be defined by general policies, but this leaves a main question to be solved: how corporations can adapt to the new situation? There must be an internal coherence between macro-economy and micro-economy, and some reflections and guidance are needed on that.

From previous sections it is obvious that a review has to be made on the different set of options available to a corporation, from technology surveillance to commercial trades, trying to reconcile the main objectives of energy policy with the success of corporations. However, if PiHFF is generally adopted, the situation will be easier, in the sense that everyone can continue with their own development, and the PiHFF will go accommodating advancements in a smooth way.

There is nonetheless a domain where oil corporations will have to develop a very active and pioneering role, because they have their own network of filling stations, which should be converted to "dual stations" including infrastructures for recharging batteries, and services for replacing them.

This is an opportunity not to miss and not to fail at, but the task is not easy. The effort ahead belongs to the field of electricity distribution and consumption management, and the typical expertise of oil corporations is very modest in those fields.

Many tasks involving standards will be needed to make such a big change possible, and some previous work can be anticipated, such as making some conceptual designs of the futuristic "dual filling stations", so that an early identification of problems, issues and needs could be done. It is obvious that this activity will be highly confidential, when applied to a given corporation and a given market, but general principles and analysis, and the figures of merits to qualify the options according to the selected criteria will be of general concern, and they will be treated in the open literature, to which this paper wishes to contribute.

\section{Acknowledgements}

The contents of this paper fully belongs to the Ph.D. Thesis of the first author (JMM-VP) who recognizes that former studies at The Colorado School of Mines and The French Institute of Petroleum offers unique opportunities to understand the world of Energy, notably the hydrocarbon sector.

\section{REFERENCES}

[1] Lawrence Livermore National Laboratory, "Science and Technology Review," 2011. https://str.llnl.gov

[2] Michigan Institute of Technology, "Technology Review," 2011. www.technologyreview.com

[3] J. Rifkin, "The Third Industrial Revolution: How Lateral Power Is Transforming Energy, the Economy, and the World," Palgrave Macmillan, Hampshire, 2011.

[4] Brundtland, "Our Common Future," Oxford University Press, New York, 1987.

[5] W. Hafele, "Energy in a Finite World. Paths to a Sustainable Future. Energy in a Finite World. A Global System Analysis,” Ballinger Pu. Co., Pensacola, 1981.

[6] T. J. Crowley and R. A. Berner, "CO 2 and Climate Change," Science, Vol. 292, No. 5518, 2001, pp. 870-872. doi:10.1126/science.1061664

[7] T. P. Barnett, D. W. Pierce and R. Schnur, "Detection of Anthropogenic Climate Change in the World's Oceans," 
Science, Vol. 292, No. 5515, 2001, pp. 270-274. doi:10.1126/science. 1058304

[8] M. Allen, "Constraints on Future Changes in Climate and the Hydrologic Cycle," Nature, Vol. 419, 2002, pp. 224227. doi:10.1038/nature01092

[9] L. Kump, "Reducing Uncertainty about Carbon Dioxide as a Climate Driver," Nature Insight, Vol. 419, No. 6903, 2002, pp. 188-190. doi:10.1038/nature01087

[10] S. F. B. Tett, J. F. B. Mitchell, D. E. Parker and M. R. Allen, "Human Influence on the Atmospheric Vertical Temperature Structure: Detection and Observations," Science, Vol. 247, 1996, pp. 1170-1173. doi:10.1126/science.274.5290.1170

[11] G. Marchuk, K. Kondratyev and V. Kozoderov, "Earth Radiation Budget," Nauka Pub, FSU, 1990.

[12] H. B. Dulal, G. Brodnig and C. G. Onoriose, "Climate Change Mitigation in the Transport Sector through Urban Planning: A Review," Habitat International, Vol. 35, No. 3, 2011, pp. 494-500. doi:10.1016/j.habitatint.2011.02.001

[13] F. Grazi and J. C. J. M. van den Bergh, "Spatial Organization, Transport, and Climate Change: Comparing Instruments of Spatial Planning and Policy," Ecological Economics, Vol. 67, No. 4, 2008, pp. 630-639. doi:10.1016/j.ecolecon.2008.01.014

[14] H. Huang, M. von Lampe and F. van Tongeren, "Climate Change and Trade in Agriculture," Food Policy, Vol. 36, 2011, pp. S9-S13. doi:10.1016/j.foodpol.2010.10.008

[15] Intergovernmental Panel on Climate Change, 2007. www.ipcc.ch Fourth Assessment Report

[16] D. Keles, D. Most and W. Fichtner, "The Development of the German Energy Market until 2030-A Critical Survey of Related Scenarios," Energy Policy, Vol. 39, No. 2, 2011, pp. 812-825. doi:10.1016/j.enpol.2010.10.055

[17] BP Statistical Review of World Energy, 2011. http://www.bp.com/sectionbodycopy.do?categoryId $=750$ $0 \&$ contentId $=7068481$

[18] World Energy Outlook, 2009. www.worldenergyoutlook.com

[19] European Union, "Green Paper: Towards a European Strategy for the Security of Energy Supply," 2000.

[20] Red Eléctrica de España. http://www.ree.es/sistema_electrico/pdf/infosis/sintesis_R EE_2010.pdf

[21] European Commission, "EUROSTAT: Energy Yearly Statistics," Office for Official Publications of the EU, Luxembourg, 2008.

[22] P. del Río and G. Unruh, "Overcoming the Lock-Out of Renewable Energy Technologies in Spain: The Cases of Wind and Solar Electricity," Renewable and Sustainable Energy Reviews, Vol. 11, No. 7, 2007, pp. 1498-1513. doi:10.1016/j.rser.2005.12.003

[23] G. M. Montes, E. P. Martín and J. O. García, "The Current Situation of Wind Energy in Spain," Renewable and Sustainable Energy Reviews, Vol. 11, No. 3, 2007, pp. 467-481. doi:10.1016/j.rser.2005.03.002

[24] Y. Perez and F. J. Ramos-Real, "The Public Promotion of
Wind Energy in Spain from the Transaction Costs Perspective 1986-2007," Renewable and Sustainable Energy Reviews, Vol. 13, No. 5, 2009, pp. 1058-1066. doi:10.1016/j.rser.2008.03.010

[25] G. M. Montes, M. M. S. López, M. C. R. Gámez and A. M. Ondina, "An Overview of Renewable Energy in Spain. The Small Hydro-Power Case," Renewable and Sustainable Energy Reviews, Vol. 9, No. 5, 2005, pp. 521-534. doi:10.1016/j.rser.2004.05.008

[26] F. Hernández, M. A. Gual, P. Del Río and A. Caparrós, "Energy Sustainability and Global Warming in Spain," Energy Policy, Vol. 32, No. 3, 2004, pp. 383-394. doi:10.1016/S0301-4215(02)00308-7

[27] F. Foidart, J. Oliver-Solá, C. M. Gasol, X. Gabarrell and J. Rieradevall, "How Important Are Current Energy Mix Choices on Future Sustainability? Case Study: Belgium and Spain-Projections towards 2020-2030," Energy Policy, Vol. 38, No. 9, 2010, pp. 5028-5037. doi:10.1016/j.enpol.2010.04.028

[28] C. Batlle and P. Rodilla, "A Critical Assessment of the Different Approaches Aimed to Secure Electricity Generation Supply," Energy Policy, Vol. 38, No. 11, 2010, p. 7169. doi:10.1016/i.enpol.2010.07.039

[29] F. Moreno and J. M. Martinez-Val, "Collateral Effects of Renewable Energies Deployment in Spain: Impact on Thermal Power Plants Performance and Management," Energy Policy, Vol. 39, No. 10, 2011, pp. 6561-6574. doi:10.1016/j.enpol.2011.07.061

[30] International Partnership for Hydrogen and Fuel Cells in the Economy, 2011. www.iphe.net

[31] D. Keith and A. Farrell, "Rethinking Hydrogen Cars," Science, Vol. 301, No. 5631, 2003, pp. 315-316. doi:10.1126/science. 1084294

[32] L. Barreto, A. Makihira and K. Riahi, "The Hydrogen Economy in the 21st Century: A Sustainable Development Scenario," International Journal of Hydrogen Energy, Vol. 28, No. 3, 2003, pp. 267-284. doi:10.1016/S0360-3199(02)00074-5

[33] H. S. Lee, K. S. Jeong and B. S. Oh, "An Experimental Study of Controlling Strategies and Drive Forces for Hydrogen Fuel Cell Hybrid Vehicles," International Journal of Hydrogen Energy, Vol. 28, No. 2, 2003, pp. 215-222. doi:10.1016/S0360-3199(02)00038-1

[34] S. G. Chalk and J. E. Miller, "Key Challenges and Recent Progress in Batteries, Fuel Cells, and Hydrogen Storage for Clean Energy Systems," Journal of Power Sources, Vol. 159, No. 1, 2006, pp. 73-80. doi:10.1016/j.jpowsour.2006.04.058

[35] H. Turton, "Sustainable Global Automobile Transport in the 21st Century: An Integrated Scenario Analysis," Technological Forecasting \& Social Change Vol. 73, No. 6, 2006, pp. 607-629. doi:10.1016/j.techfore.2005.10.001

[36] A. Ford, "Electric Vehicle and the Electric Utility Company," Energy Policy, Vol. 22, No. 7, 1994, pp. 555-570. doi:10.1016/0301-4215(94)90075-2

[37] R. Cowan and S. Hulten, "Escaping Lock-In: The Case of the Electric Vehicle," Technology Forecasting and Social Change, Vol. 53, No. 1, 1996, pp. 61-79. doi:10.1016/0040-1625(96)00059-5 
[38] G. G. Harding, "Electrical Vehicles in the Next Millennium," Journal of Power Sources, Vol. 78, No. 1-2, 1999, pp. 193-198. doi:10.1016/S0378-7753(99)00037-3

[39] M. Wada, "Research and Development of Electrical Vehicles for Clean Transportation," Journal of Environmental Science, Vol. 21, No. 6, 2009, pp. 745-749. doi:10.1016/S1001-0742(08)62335-9

[40] S. Brown, D. Pyke and P. Steenhof, "Electric Vehicles: The Role and Importance of Standards in an Emerging Market," Energy Policy, Vol. 38, No. 7, 2010, pp. 37973806. doi:10.1016/j.enpol.2010.02.059

[41] R. Webster, "Can the Electricity Distribution Network Cope with an Influx of Electric Vehicles?" Journal of Power Sources, Vol. 80, No. 1-2, 1999, pp. 217-225. doi:10.1016/S0378-7753(98)00262-6

[42] A. K. Srivastava, B. Annabathina and S. Kamalasadan, "The Challenges and Policy Options for Integrating Plugin Hybrid Electric Vehicle into the Electric Grid," The Electricity Journal, Vol. 23, No. 3, 2010, pp. 83-91. doi:10.1016/i.tej.2010.03.004

[43] W. Kempton and S. Letendre, "Electric Vehicles as a New Source of Power for Electric Utilities," Transportation Research, Vol. 2, No. 3, 1997, pp. 157-175.

[44] Generation 4 Forum Website, 2011. www.gen-4.org

[45] B. Sorensen, "Renewable Energies," 2nd Edition, Academic Press, Inc., New York, 2002.

[46] Carbon Sequestration Leadership Forum Website, 2011. www.cslf.org.

[47] H. Terrell, "US Gas Reserves Estimated at Record High," World Oil, Vol. 232, No. 5, 2011, p. 13.

[48] K. Costello, “Going 'Long' with Natural Gas?” The Electricity Journal, Vol. 24, No. 5, 2011, pp. 42-49. doi:10.1016/j.tej.2011.05.005

[49] T. C. Kinnaman, "The Economic Impact of Shale Gas Extraction: A Review of Existing Studies," Ecological Economics, Vol. 70, No. 7, 2011, pp. 1243-1249. doi:10.1016/j.ecolecon.2011.02.005

[50] R. Mcllvaine and A. James, "The Potential of Shale Gas," World Pumps, Vol. 7, 2010, pp. 16-18. doi:10.1016/S0262-1762No. 10)70195-4

[51] B. Buffet and D. Archer, "Global Inventory of Methane Clathrate: Sensitivity to Changes in the Deep Ocean," Earth and Planetary Science Letters, Vol. 227, 2004, pp. 185-199. doi:10.1016/j.eps1.2004.09.005

[52] A. Demirbas, "Methane Hydrates as Potential Energy Resource: Part 1-Importance, Resource and Recovery Facilities," Energy Conversion and Management, Vol. 51, No. 7, 2010, pp. 1547-1561. doi:10.1016/j.enconman.2010.02.013

[53] A. Demirbas, "Methane Hydrates as Potential Energy Resource: Part 2-Methane Production Processes from Gas Hydrates," Energy Conversion and Management, Vol. 51, No. 7, 2010, pp. 1562-1571. doi:10.1016/j.enconman.2010.02.014

[54] K. A. Kvenvolden, "Methane Hydrate-A Major Reservoir of Carbon in the Shallow Geosphere?" Chemical Geology, Vol. 71, No. 1-3, 1988, pp. 41-51. doi:10.1016/0009-2541(88)90104-0
[55] S. Lee and G. D. Holder, "Methane Hydrates Potential as a Future Energy Source," Fuel Processing Technology, Vol. 71, No. 1-3, 2001, pp. 181-186. doi:10.1016/S0378-3820No. 01)00145-X

[56] K. H. Robert, B. Schmidt-Bleek, J. A. De Larderel, G. Basile, J. L. Jansen, R. Kuehr, P. P. Thomas, et al., "Strategic Sustainable Development-Selection, Design and Synergies of Applied Tools" Journal of Cleaner Production, Vol. 10, No. 3, 2002, pp. 197-214. doi:10.1016/S0959-6526No. 01)00061-0

[57] J. Korhonen, "Industrial Ecology in the Strategic Sustainable Development Model: Strategic Applications of Industrial Ecology," Journal of Cleaner Production, Vol. 12, No. 8-10, 2004, pp. 809-823. doi:10.1016/i.jclepro.2004.02.026

[58] K. H. Robèrt, "Tools and Concepts for Sustainable Development, How Do They Relate to a General Framework for Sustainable Development, and to Each Other?" Journal of Cleaner Production, Vol. 8, No. 3, 2000, pp. 243254. doi:10.1016/S0959-6526No. 00)00011-1

[59] J. R. Ehrenfeld, "Industrial Ecology: Paradigm Shift or Normal Science?" American Behavioral Scientist, Vol. 44, No. 2, 2000, pp. 229-244.

[60] T. E. Graedel and B. R. Allenby, "Industrial Ecology," Academy of Management Review, Vol. 20, No. 1, 1995, pp. 1968-1975.

[61] S. Erkman, "Industrial Ecology: Historical View," Journal of Cleaner Production, Vol. 5, No. 1-2, 1997, pp. 110. doi:10.1016/S0959-6526No. 97)00003-6

[62] H. E. Daly, "Beyond Growth: The Economics of Sustainable Development," Beacon Press, Boston, 1996.

[63] K. L. Anderson, "Reconciling the Electricity Industry with Sustainable Development: Backcasting - A Strategic Alternative," Futures, Vol. 33, No. 7, 2001, pp. 607-623. doi:10.1016/S0016-3287No. 01)00004-0

[64] J. Kuisma, "Backcasting for Sustainable Strategies in the Energy Sector: A Case Study in FORTUM Power and Heat," The International Institute for Industrial Environmental Economics, Sweden, 2000.

[65] R. Williams, "Roles for Biomass Energy in Sustainable Development," Industrial Ecology and Global Change, 1994, pp. 199-228.

[66] F. Figgea and T. Hahn, "Sustainable Value Added-Measuring Corporate Contributions to Sustainability beyond Eco-Efficiency," Ecological Economics, Vol. 48, 2004, pp. 173-187. doi:10.1016/j.ecolecon.2003.08.005

[67] E. Heiskanen, "The Institutional Logic of Life Cycle Thinking," Journal of Cleaner Production, Vol. 10, No. 5, 2002, pp. 427-437. doi:10.1016/S0959-6526No. 02)00014-8

[68] N. Darnall, I. Henriques and P. Sadorsky, "Do Environmental Management Systems Improve Business Performance in an International Setting?" Journal of International Management, Vol. 14, No. 4, 2008, pp. 364-376. doi:10.1016/j.intman.2007.09.006

[69] R. D. Klassen and C. P. McLaughlin, "The Impact of Environmental Management on Firm Performance," Management Science, Vol. 42, No. 8, 1996, pp. 1199-1214. doi:10.1287/mnsc.42.8.1199 
[70] L. Matzny, "Biofuels for Transport: Global Potential and Implications for Energy and Agriculture," Worldwatch Institute, Earthscan Ltd., 2007.

[71] T. Mattila and R. Antikainen, "Backcasting Sustainable Freight Transport Systems for Europe in 2050," Energy Policy, Vol. 39, No. 3, 2011, pp. 1241-1248. doi:10.1016/j.enpol.2010.11.051

[72] P. Moriarty and D. Honnery, "Low-Mobility: The Future of Transport," Futures, Vol. 40, No. 10, 2008, pp. 865872. doi:10.1016/j.futures.2008.07.021

[73] D. Giurco, B. Cohen, E. Langham and M. Warnken, "Backcasting Energy Futures Using Industrial Ecology," Technological Forecasting and Social Change, Vol. 78, No. 5, 2011, pp. 797-818. doi:10.1016/j.techfore.2010.09.004

[74] P. Moriarty and D. Honnery, "The Prospects for Global Green Car Mobility," Journal of Cleaner Production, Vol. 16 No. 16, 2008, pp. 1717-1726. doi:10.1016/j.jclepro.2007.10.025

[75] C. E. Thomas, "Fuel Cell and Battery Electric Vehicles Compared, International," Journal of Hydrogen Energy, Vol. 34, No. 15, 2009, pp. 6005-6020. doi:10.1016/j.ijhydene.2009.06.003

[76] K. Ç. Bayindir, M. A. Gözüküçük and A. Teke, "A Comprehensive Overview of Hybrid Electric Vehicle: Powertrain Configurations, Powertrain Control Techniques and Electronic Control Units," Energy Conversion and Management, Vol. 52, No. 2, 2011, pp. 1305-1313. doi:10.1016/j.enconman.2010.09.028

[77] G. J. Offer, M. Contestabile, D. A. Howey, R. Clague and N. P. Brandon, "Techno-Economic and Behavioural Analysis of Battery Electric, Hydrogen Fuel Cell and Hybrid Vehicles in a Future Sustainable Road Transport System in the UK," Energy Policy, Vol. 39, 2011, pp. 1939-1950. doi:10.1016/j.enpol.2011.01.006

[78] G. Gutmann, "Hybrid Electric Vehicles and Electrochemical Storage Systems-A Technology Push-Pull Couple," Journal of Power Sources, Vol. 84, No. 2, 1999, pp. 275279. doi:10.1016/S0378-7753No. 99)00328-6

[79] T. Kojimaa, T. Ishizua, T. Horibaa and M. Yoshikawa, "Development of Lithiumion Battery for Fuel Cell Hybrid Electric Vehicle Application," Journal of Power Sources, Vol. 189, No. 1, 2009, pp. 859-863. doi:10.1016/j.jpowsour.2008.10.082

[80] J. Van Mierlo, G. Maggetto and Ph. Lataire, "Which Energy Source for Road Transport in the Future? A Comparison of Battery, Hybrid and Fuel Cell Vehicles," Energy Conversion and Management, Vol. 47, No. 17, 2006, pp. 2748-2760. doi:10.1016/j.enconman.2006.02.004

[81] T. H. Bradley and A. A. Frank, "Design, Demonstrations and Sustainability Impact Assessments for Plug-in Hybrid Electric Vehicles," Renewable and Sustainable Energy Reviews, Vol. 13, No. 1, 2009, pp. 115-128. doi:10.1016/j.rser.2007.05.003

[82] S. Amjad, S. Neelakrishnan and R. Rudramoorthy, "Review of Design Considerations and Technological Challenges for Successful Development and Deployment of Plug-in Hybrid Electric Vehicles," Renewable and Sustainable Energy Reviews, Vol. 14, No. 3, 2010, pp. 11041110. doi:10.1016/i.rser.2009.11.001
[83] Annual Energy Outlook 2011, with Projections to 2035 No. 2011, Report \#:DOE/EIA-0383, 2011. www.eia.gov

[84] W. Liao, R. Heijungs and G. Huppes, "Is Bioethanol a Sustainable Energy Source? An Energy-, Exergy-, and Emergy-Based Thermodynamic System Analysis," Renewable Energy, Vol. 36, No. 12, 2011, pp. 3479-3487. doi:10.1016/j.renene.2011.05.030

[85] L. Luo, E. Van Der Voet and G. Huppes, "Life Cycle Assessment and Life Cycle Costing of Bioethanol from Sugarcane in Brazil," Renewable and Sustainable Energy Reviews, Vol. 13, No. 6-7, 2009, pp. 1613-1619. doi:10.1016/j.rser.2008.09.024

[86] E. Hanff, M.-H. Dabat and J. Blin, “Are Biofuels an Efficient Technology for Generating Sustainable Development in Oil-Dependent African Nations? A Macroeconomic Assessment of the Opportunities and Impacts in Burkina Faso," Renewable and Sustainable Energy Reviews, Vol. 15, No. 5, 2011, pp. 2199-2209. doi:10.1016/j.rser.2011.01.014

[87] R. Melamu and H. Von Blottnitz, "2nd Generation Biofuels a Sure Bet? A Life Cycle Assessment of How Things Could Go Wrong," Journal of Cleaner Production, Vol. 19, No. 2-3, 2010, pp. 138-144. doi:10.1016/j.jclepro.2010.08.021

[88] Lake Nyox Data. http://www.geo.arizona.edu/geo5xx/geos577/projects/kay $\mathrm{zar} / \mathrm{html} /$ lake_nyos_disaster.html

[89] http://www.geology.sdsu.edu/how_volcanoes_work/Nyos .html

[90] Nuclear Regulatory Commission, 2011. www.nrc.gov

[91] A. Ritchie and W. Howard, "Recent Developments and Likely Advances in Lithium-Ion Batteries," Journal of Power Sources, Vol. 162 No. 2, 2006, pp. 809-812. doi:10.1016/j.jpowsour.2005.07.014

[92] T. M. Bandhauer, S. Garimella and T. F. Fuller, "A Critical Review of Thermal Issues in Lithium-Ion Batteries," Journal of the Electrochemical Society, Vol. 158, No. 3, 2011, pp. R1-R25. doi:10.1149/1.3515880

[93] M. Park, X. Zhang, M. Chung, G. B. Less and A. M. Sastry, "A Review of Conduction Phenomena in Li-Ion Batteries," Journal of Power Sources, Vol. 195, No. 24, 2010, pp. 7904-7929. doi:10.1016/j.jpowsour.2010.06.060

[94] L. Damen, M. Lazzari and M. Mastragostino, "Safe Lithium-Ion Battery with Ionic Liquid-Based Electrolyte for Hybrid Electric Vehicles," Journal of Power Sources, Vol. 196, No. 20, 2011, pp. 8692-8695. doi:10.1016/j.jpowsour.2011.06.005

[95] M. Amiri, M. Esfahanian, M. Reza Hairi-Yazdi and V. Esfahanian, "Minimization of Power Losses in Hybrid Electric Vehicles in View of the Prolonging of Battery Life," Journal of Power Sources, Vol. 190, No. 2, 2009, pp. 372-379. doi:10.1016/j.jpowsour.2009.01.072

[96] P. Roberts, "The Last Drops: How to Bridge the Gap between Oil and Green Energy," Popular Science, 2011.

[97] Y. F. Makogon, "Perspectives for the Development of Gas Hydrate Deposits," 1982. http://pubs.aina.ucalgary.ca/cpc/CPC4-299.pdf

[98] T. S. Collett, "Energy Resource Potential of Natural Gas 
Hydrates," AAPG Bulletin, Vol. 86, No. 11, 2002, pp. 19711992.

[99] G. J. Moridis, et al., "Toward Production from Gas Hydrates: Current Status, Assessment of Resources, and ModelBased Evaluation of Technology and Potential," 2008, SPE 114163.

[100] Y. F. Makogon, "Natural Gas Hydrates-A Promising Source of Energy," Journal of Natural Gas Science and Engineering, Vol. 2, No. 1, 2010, pp. 49-59. doi:10.1016/j.jngse.2009.12.004

[101] T. M. Odell, "High Efficiency Flexfuel Internal Combustion Engine," USA Patent Application US 2008/0041057 A1, 2009.

[102] C. Park, Y. Choi, C. Kim, S. Oh, G. Lim and Y. Moriyoshi, "Performance and Exhaust Emission Characteristics of a Spark Ignition Engine Using Ethanol and EthanolReformed Gas," Fuel, Vol. 89, No. 8, 2010, pp. 21182125. doi:10.1016/i.fuel.2010.03.018

[103] H. Lee, C.-L. Myung and S. Park, "Time-Resolved Particle Emission and Size Distribution Characteristics during Dynamic Engine Operation Conditions with EthanolBlended Fuels," Fuel, Vol. 88, No. 9, 2009, pp. 16801686. doi:10.1016/j.fuel.2009.03.007

[104] C. P. Cooney, J. J. Worm and J. D. Naber, "Combustion Characterization in an Internal Combustion Engine with Ethanol-Gasoline Blended Fuels Varying Compression Ratios and Ignition Timing," Energy and Fuels, Vol. 23, No. 5, 2009, pp. 2319-2324. doi:10.1021/ef800899r

[105] G. Festel, "Bio Motor Fuels-A Comparative Analysis of Manufacturing Costs and Market Opportunities," ChemieIngenieur-Technik, Vol. 78, No. 9, 2006, pp. 1175. doi:10.1002/cite. 200650010

[106] G. Valentino, F. E. Corcione, S. E. Iannuzzi and S. Serra, "Experimental Study on Performance and Emissions of a High Speed Diesel Engine Fuelled with N-Butanol Diesel Blends under Premixed Low Temperature Combustion," Fuel, Vol. 92, No. 1, 2012, pp. 295-307. doi:10.1016/j.fuel.2011.07.035

[107] Y.-H. Chen, T.-H. Chiang and J.-H. Chen, "An Optimum Biodiesel Combination: Jatropha and Soapnut Oil Biodiesel Blends," Fuel, Vol. 92, No. 1, 2012, pp. 377-380. doi:10.1016/j.fuel.2011.08.018

[108] S. K. Hoekman, A. Broch, C. Robbins, E. Ceniceros and M. Natarajan, "Review of Biodiesel Composition, Properties, and Specifications," Renewable and Sustainable Energy Reviews, Vol. 16, No. 1, 2012, pp. 143-169. doi:10.1016/j.rser.2011.07.143

[109] X. Fan and R. Burton, "Recent Development of Biodiesel Feedstocks and the Applications of Glycerol: A Review," Open Fuels and Energy Science Journal, Vol. 2, 2009, pp. 100-109. doi:10.2174/1876973X00902010100

[110] S. K. Hoekman, A. W. Gertler, A. Broch, C. Robbins and M. Natarajan, "Biodistillate Transportation Fuels 1. Production and Properties," SAE International Journal of Fuels and Lubricants, Vol. 2, No. 2, 2010, pp. 185-232.

[111] R. Sarin, R. Kumar, B. Srivastav, S. K. Puri, D. K. Tuli, R. K. Malhotra and A. Kumar, "Biodiesel Surrogates: Achieving Performance Demands," Bioresource Technology, Vol.
100, No. 12, 2009, pp. 3022-3028. doi:10.1016/j.biortech.2009.01.032

[112] S. Bezergianni, K. Kalogeras and P. A. Pilavachi, "On Maximizing Biodiesel Mixing Ratio Based on Final Product Specifications," Computers and Chemical Engineering, Vol. 35, No. 5, 2011, pp. 936-942. doi:10.1016/j.compchemeng.2011.01.034

[113] S. Lim and L. K. Teong, "Recent Trends, Opportunities and Challenges of Biodiesel in Malaysia: An Overview," Renewable and Sustainable Energy Reviews, Vol. 14, No. 3, 2010, pp. 938-954. doi:10.1016/j.rser.2009.10.027

[114] A. Sarin, R. Arora, N. P. Singh, R. Sarin, R. K. Malhotra and S. Sarin, "Blends of Biodiesels Synthesized from Non-Edible and Edible Oils: Effects on the Cold Filter Plugging Point," Energy and Fuels, Vol. 24, No. 3, 2010, pp. 1996-2001. doi:10.1021/ef901131m

[115] L. Azócar, G. Ciudad, H. J. Heipieper and R. Navia, "Biotechnological Processes for Biodiesel Production Using Alternative Oils," Applied Microbiology and Biotechnology, Vol. 88, No. 3, 2010, pp. 621-636. doi:10.1007/s00253-010-2804-Z

[116] S. K. Hoekman, A. W. Gertler, A. Broch, C. Robbins and M. Natarajan, "Biodistillate Transportation Fuels 1. Production and Properties," SAE International Journal of Fuels and Lubricants, Vol. 2, No. 2, 2010, pp. 185-232.

[117] S. Jain and M. P. Sharma, "Stability of Biodiesel and Its Blends: A Review," Renewable and Sustainable Energy Reviews, Vol. 14, No. 2, 2010, pp. 667-678. doi:10.1016/j.rser.2009.10.011

[118] R. D. Misra and M. S. Murthy, "Straight Vegetable Oils Usage in a Compression Ignition Engine-A Review," Renewable and Sustainable Energy Reviews, Vol. 14, No. 9, 2010, pp. 3005-3013. doi:10.1016/j.rser.2010.06.010

[119] M. Y. Koh and T. I. Mohd. Ghazi, "A Review of Biodiesel Production from Jatropha curcas L. Oil," Renewable and Sustainable Energy Reviews, Vol. 15, No. 5, 2011, pp. 2240-2251. doi:10.1016/j.rser.2011.02.013

[120] A. Bostrom, R. E. O’Connor, G. Böhm, D. Hanss, O. Bodi, F. Ekström and P. Halder, "Causal Thinking and Support for Climate Change Policies: International Survey Findings," Global Environmental Change, Vol. 22, No. 1, 2011, pp. 210-222. doi:10.1016/j.gloenvcha.2011.09.012

[121] C. Williams, "Earth Shattering: How Global Warming Will Shake Up the Planet," New Scientist, Vol. 211, No. 2832, 2011, pp. 38-42. doi:10.1016/S0262-4079No. 11)62404-4

[122] S. Solomon, J. S. Daniel, R. R. Neely III, J.-P. Vernier, E. G. Dutton and L. W. Thomason, "The Persistently Variable 'Background' Stratospheric Aerosol Layer and Global Climate Change," Science, Vol. 333, No. 6044, 2011, pp. 866-870. doi: $10.1126 /$ science. 1206027

[123] A. Robock, "Volcanic Eruptions and Climate," Reviews of Geophysics, Vol. 38, No. 2, 2000, pp. 191-219. doi:10.1029/1998RG000054

[124] B. M. Harris and E. J. Highwood, "A Simple Relationship between Volcanic Sulfate Aerosol Optical Depth and Surface Temperature Change Simulated in an AtmosphereOcean General Circulation Model," Journal of Geophysical Research: Atmospheres, Vol. 116, No. 5, 2011, Arti- 
cle ID: D05109. doi:10.1029/2010JD014581

[125] G. M. Miles, R. G. Grainger and E. J. Highwood, "The Significance of Volcanic Eruption Strength and Frequency for Climate," Quarterly Journal of the Royal Meteorological Society, Vol. 130, No. 602, 2004, pp. 2361-2376. doi:10.1256/qj.03.60

[126] A. V. Eliseev and I. I. Mokhov, "Influence of Volcanic Activity on Climate Change in the Past Several Centuries: Assessments with a Climate Model of Intermediate Complexity," Atmospheric and Ocean Physics, Vol. 44, No. 6, 2008, pp. 671-683. doi:10.1134/S0001433808060017

[127] M. Free and A. Robock, "Global Warming in the Context of the Little Ice Age," Journal of Geophysical Research D: Atmospheres, Vol. 104, No. D16, 1999, pp. 1905719070. doi:10.1029/1999JD900233

[128] G. A. Zielinski, "Use of Paleo-Records in Determining Variability within the Volcanism-Climate System," Quaternary Science Reviews, Vol. 19, No. 1-5, 2000, pp. 417438.

[129] D. I. Axelrod, "Role of Volcanism in Climate and Evolution," Special Paper, 185, Geological Society of America, Boulder, CO., 1981.

[130] J. R. Bray, "Volcanic Triggering of Glaciation," Nature, Vol. 260, No. 5550, 1976, pp. 414-415. doi: $10.1038 / 260414 \mathrm{a} 0$

[131] R. A. Bryson and B. M. Goodman, "Volcanic Activity and Climatic Changes," Science, Vol. 207, No. 4435, 1980, pp. 1041-1044. doi:10.1126/science.207.4435.1041

[132] B.-K. Moon, D. Youn, R. J. Park, S.-W. Yeh, W.-M. Kim, Y.-H. Kim, J. I. Jeong, et al., "Meteorological Responses to Mt. Baekdu Volcanic Eruption over East Asia in an Offline Global Climate-Chemistry Model: A Pilot Study," Asia-Pacific Journal of Atmospheric Sciences, Vol. 47, No. 4, 2011, pp. 345-351. doi:10.1007/s13143-011-0021-Z

[133] T. Yuan, L. A. Remer and H. Yu, "Microphysical, Macrophysical and Radiative Signatures of Volcanic Aerosols in Trade Wind Cumulus Observed by the A-Train," Atmospheric Chemistry and Physics, Vol. 11, No. 14, 2011, pp. 7119-7132. doi:10.5194/acp-11-7119-2011

[134] F. Yang and M. E. Schlesinger, "Identification and Separation of Mount Pinatubo and El Niño-Southern Oscillation Land Surface Temperature Anomalies," Journal of Geophysical Research D: Atmospheres, Vol. 106, No. D14, 2001, pp. 14757-14770. doi:10.1029/2001JD900146

[135] A. G. Marshall, A. A. Scaife and S. Ineson, "Enhanced Seasonal Prediction of European Winter Warming Following Volcanic Eruptions," Journal of Climate, Vol. 22, No. 23, 2009, pp. 6168-6180. doi:10.1175/2009JCLI3145.1

[136] D. E. Parker, H. Wilson, P. D. Jones, J. R. Christy and C. K. Folland, "The Impact of Mount Pinatubo on WorldWide Temperatures," International Journal of Climatology, Vol. 16, No. 5, 1996, pp. 487-497. doi:10.1002/No.SICI)1097-0088No.199605)16:5<487::A ID-JOC39>3.0.CO;2-J

[137] J. K. Angell, "Impact of El Nino on the Delineation of Tropospheric Cooling Due to Volcanic Eruptions," Jour- nal of Geophysical Research, Vol. 93, No. D4, 1988, pp. 3697-3704. doi:10.1029/JD093iD04p03697

[138] S. Bekki, J. A. Pyle, W. Zhong, R. Toumi, J. D. Haigh and D. M. Pyle, "The Role of Microphysical and Chemical Processes in Prolonging the Climate Forcing of the Toba Eruption," Geophysical Research Letters, Vol. 23 No. 19, 1996, pp. 2669-2672. doi:10.1029/96GL02088

[139] G. J. S. Bluth, S. D. Doiron, C. C. Schnetzler, A. J. Krueger and L. S. Walter, "Global Tracking of the $\mathrm{SO}_{2}$ Clouds from the June, 1991 Mount Pinatubo Eruptions," Geophysical Research Letters, Vol. 19, No. 2, 1992, pp. 151154. doi:10.1029/91GL02792

[140] R. D. Cadle, "Comparison of Volcanic with Other Fluxes of Atmospheric Trace Gas Constituents," Reviews of Geophysics and Space Physics, Vol. 18, No. 4, 1980, pp. 746752. doi:10.1029/RG018i004p00746

[141] J. Cole-Dai, E. Mosley-Thompson and L. G. Thompson, "Quantifying the Pinatubo Volcanic Signal in South Polar Snow," Geophysical Research Letters, Vol. 24, No. 21, 1977, pp. 2679-2682. doi:10.1029/97GL02734

[142] M. P. McCormick, L. W. Thomason and C. R. Trepte, "Atmospheric Effects of the Mt Pinatubo Eruption," Nature, Vol. 373, No. 6513, 1995, pp. 399-404. doi: $10.1038 / 373399 \mathrm{a} 0$

[143] G. Gu and R. F. Adler, "Large-Scale, Inter-Annual Relations among Surface Temperature, Water Vapour and Precipitation with and without ENSO and Volcano Forcings," International Journal of Climatology, Vol. 32, No. 12, 2012, pp. 1782-1791. doi:10.1002/joc.2393

[144] J. Boulon, K. Sellegri, M. Hervo and P. Laj, "Observations of Nucleation of New Particles in a Volcanic Plume," Proceedings of the National Academy of Sciences of the United States of America, Vol. 108, No. 30, 2011, pp. 12223-12226. doi:10.1073/pnas.1104923108

[145] S. Blake, "Correlations between Eruption Magnitude $\mathrm{SO}_{2}$ Yield, and Surface Cooling," Geological Society Special Publication, Vol. 213, 2003, pp. 371-380.

[146] D. T. Shindell, G. A. Schmidt, M. E. Mann and G. Faluvegi, "Dynamic Winter Climate Response to Large Tropical Volcanic Eruptions since 1600," Journal of Geophysical Research D: Atmospheres, Vol. 109, No. 5, 2004, pp. D05104 1-12.

[147] J. K. Angell and J. Korshover, "Surface Temperature Changes Following the Six Major Volcanic Episodes between 1780 and 1980," Journal of Climate \& Applied Meteorology, Vol. 24, No. 9, 1985, pp. 937-951. doi:10.1175/1520-0450No. 1985)0242.0.CO;2

[148] R. S. Bradley, "The Explosive Volcanic Eruption Signal in Northern Hemisphere Continental Temperature Records," Climatic Change, Vol. 12, No. 3, 1988, pp. 221243. doi:10.1007/BF00139431

[149] R. S. Bradley and P. D. Jones, "Records of Explosive Volcanic Eruptions over the Last 500 Years," Climate since A.D. 1500, 1992, pp. 606-622.

[150] J. R. Bray, "Glacial Advance Relative to Volcanic Activity since 1500 AD," Nature, Vol. 248, No. 5443, 1974, pp. 42-43. doi:10.1038/248042a0

[151] K. R. Briffa, P. D. Jones, T. S. Bartholin, D. Eckstein, F. 
H. Schweingruber, W. Karlén, P. Zetterberg and M. Eronen, "Fennoscandian Summers from AD 500: Temperature Changes on Short and Long Timescales," Climate Dynamics, Vol. 7, No. 3, 1992, pp. 111-119. doi:10.1007/BF00211153

[152] K. R. Briffa, P. D. Jones, F. H. Schweingruber and T. J. Osborn, "Influence of Volcanic Eruptions on Northern Hemisphere Summer Temperature over the Past 600 Years," Nature, Vol. 393, No. 6684, 1998, pp. 450-455. doi: $10.1038 / 30943$

[153] T. J. Crowley, T. M. Quinn, F. W. Taylor, C. Henin and P. Joannot, "Evidence for a Volcanic Cooling Signal in a 335-Year Coral Record from New Caledonia," Paleoceanography, Vol. 12, No. 5, 1997, pp. 633-639. doi:10.1029/97PA01348

[154] R. D. D'Arrigo and G. C. Jacoby, 'Northern North American Tree-Ring Evidence for Regional Temperature Changes after Major Volcanic Event," Climatic Change, Vol. 41,

\section{List of Acronyms}

CCS Carbon Capture and Sequestration

CC Climate Change

EV Electric Vehicles

EU European Union

GCC Gas-Fired Combined Cycles

GW Global Warming

GHG Greenhouse Gases
No. 1, 1999, pp. 1-15. doi:10.1023/A:1005370210796

[155] R. J. Delmas, M. Legrand, A. J. Aristarain and F. Zanolini, "Volcanic Deposits in Antarctic Snow and Ice," Journal of Geophysical Research, Vol. 90, No. D7, 1985, pp. 1290112920. doi:10.1029/JD090iD07p12901

[156] K. Grönvold, N. Óskarsson, S. J. Johnsen, H. B. Clausen, C. U. Hammer, G. Bond and E. Bard, "Ash Layers from Iceland in the Greenland GRIP Ice Core Correlated with Oceanic and Land Sediments," Earth and Planetary Science Letters, Vol. 135, No. 1-4, 1995, pp. 149-155. doi:10.1016/0012-821XNo. 95)00145-3

[157] H. H. Lamb, "Volcanic Dust in the Atmosphere, with a Chronology and Assessment of Its Meteorological Significance," Philosophical Transactions of the Royal Society of London Series A: Mathematical and Physical Science, Vol. 266, No. 1178, 1970, pp. 425-533. doi:10.1098/rsta.1970.0010

HC Hydrogen Cars

IPP.C Intergovernmental Panel on Climate Change

ICE Internal Combustion Engines

MMBPD Million Barrels of Oil per Day

NG Natural Gas

PiHFF Plug-In Hybrid Car with Flexible Fuel

RE Renewable Energies

RES Renewable Energy Sources 